\title{
Prognosis Masyarakat Muslim Terhadap Paradigma Pengubatan Islam di Malaysia
}

\author{
Khadher Ahmad \\ Universiti Malaya, khadher82@um.edu.my \\ Muhammad Ikhlas Rosele \\ Universiti Malaya, ikhlas@um.edu.my \\ Mohd Farhan Md Ariffin \\ Universiti Malaya, al.muqarrobuun@gmail.com \\ DOI: https://doi.org/10.22452/usuluddin.vol47no2.5
}

\begin{abstract}
Abstrak
Pengubatan Islam merupakan kaedah penyembuhan penyakit berdasarkan hukum syarak oleh orang yang mahir dengan kaedah rawatan yang dilakukan semata-mata kerana Allah SWT. Bagi majoriti negara Muslim, subjek adalah metode yang popular dalam penjagaan kesihatan. Walau bagaimanapun, belum wujud sebarang bentuk program kesihatan berbentuk praktik rawatan dan pencegahan penyakit berasaskan pengubatan Islam secara komprehensif di mana-mana negara sehingga kini. Ini membuktikan pengubatan Islam belum mampu untuk tampil sebaris dengan model kesihatan bawaan Barat. Demikian bagi menilai potensi jalinan integrasi antara pengubatan Islam dan moden di Malaysia, artikel ini memfokuskan persepsi masyarakat Muslim berkenaan prospek masa depan pengubatan Islam yang didapati hasil daripada analisis borang soal selidik. Para responden terdiri daripada 379 orang pesakit yang mengunjungi sejumlah 70 buah pusat pengubatan Islam di Malaysia. Hasil kajian mendapati persepsi tahap tinggi ditunjukkan responden terhadap prospek pengubatan Islam. Hal ini menunjukkan kepekaan populasi kajian terhadap kewujudan, peranan dan kepentingan pengubatan Islam di Malaysia. Kombinasi bersama pengubatan Islam dengan sistem perubatan moden dijangka mampu direalisasikan, termasuk mewujudkan satu kurikulum pengubatan yang lebih berautoriti. Rumusan kajian ini berguna sebagai panduan dalam memahami kehendak masyarakat dalam memacu hala tuju pengubatan Islam di Malaysia.
\end{abstract}

Kata kunci: pengubatan Islam, adaptasi Islam, Islam futuristik, integrasi Islam 


\title{
Prognosis of Muslim Society on Islamic Medicine Paradigm in Malaysia
}

\begin{abstract}
Islamic medicine is a method of diseases healing based on Islamic law by those who are proficient with the treatment performed solely for Allah. For most Muslim countries, the subject is a popular method of healthcare. However, there has not been any comprehensive health program in the form of comprehensive Islamic medicine-based treatment and prevention in any country to date. This proves that Islamic medicine has not been able to come in line with Western health models. To assess the potential for integration between Islamic and modern medicine in Malaysia, this article focuses on the Muslim community's perception of the future prospects of Islamic medicine as a result of the questionnaire analysis. The respondents consisted of 379 patients who visited a total of 70 Islamic medical centers in Malaysia. The study found that respondents' high level of perception towards Islamic alternative treatment prospects. This indicates the sensitivity of the study population to the existence, role and importance of Islamic medicine in Malaysia. The combination of Islamic medicine with the modern medical system is expected to be realized, including the creation of a more powerful medical curriculum. The findings of this study are useful as a guide in understanding the needs of the community in driving the direction of Islamic medicine in Malaysia.
\end{abstract}

Keywords: Islamic medicine, adaptation of Islam, Islamic futuristic, integration of Islam

\section{Pendahuluan}

Traditional Arabic and Islamic Medicine (TAIM) merupakan suatu metode pengubatan yang diterima secara meluas dalam dunia Islam. Sebagai contoh, subjek mendapat perhatian penduduk yang berada dalam lingkungan Mediterranean, selari dengan kepercayaan mereka terhadap pengubat rohani (spiritual healers). Dalam pada itu, TAIM turut menjadi pilihan utama dalam mengubati penyakit seperti isu kesuburan, sawan dan stres. Selain daripada itu, TAIM didapati berjaya merawat beberapa penyakit akut dan kronik. Realiti ini telah memartabatkan TAIM sebagai kaedah pengubatan yang semakin menarik minat golongan saintifik. ${ }^{1}$

1 Norhafizah Musa \& Che Zarrina Sa'ari, "Pendekatan Psikoterapi Islam dalam Menguruskan Tekanan Pesakit Kronik", Jurnal Usuluddin 47, 1 (2019): 1-34. 
Malaysia juga tidak terkecuali dalam penerimaan rawatan berasaskan TAIM. Hal tersebut boleh dibuktikan dengan perkembangannya melalui pertumbuhan pusat-pusat rawatan. Berdasarkan maklumat pada tahun 2014, jumlah pusat rawatan Islam yang telah ditubuhkan di Malaysia dianggarkan melebihi daripada 100 buah. $^{2}$ Angka ini adalah satu angka yang besar dan signifikan untuk membuktikan perkembangan dan penerimaan positif terhadap pusat rawatan Islam di Malaysia.

Akan tetapi, dari perspektif yang lebih global, pengubatan Islam dilihat masih belum diterima sepenuhnya sebagai salah satu komponen penjagaan dan rawatan kesihatan utama. Walaupun secara teori dan perkembangannya, TAIM mempunyai daya saing selari dengan penerimaan masyarakat, akan tetapi realitinya tetap belum mampu menawarkan kaedah rawatan dan penjagaan kesihatan yang kondusif. Sedangkan subjek merupakan satu kekuatan model kesihatan yang dipelopori Barat $^{3}$ yang telah meliputi aspek diagnosis, rawatan dan pencegahan penyakit. Manakala, pengubatan Islam masih belum menyediakan secara komprehensif meliputi aspek-aspek tersebut di mana-mana negara. ${ }^{4}$

Berlandaskan kenyataan tersebut, kajian dijalankan dengan tujuan meneliti kepentingan atau signifikan pengubatan Islam di Malaya. Kajian akan menilai persepsi masyarakat berkenaan prospek TAIM pada masa hadapan. Data-data yang dikemukakan juga adalah penting untuk dirujuk bagi pemerkasaan dan penambah baikan pengubatan Islam di Malaysia khususnya.

\section{Senarai Pusat-pusat Rawatan Islam di Malaysia}

Dalam kajian antara tahun 2008-2013, pengkaji telah menyenaraikan sebanyak 70 buah pusat rawatan Islam dalam

2 Khadher Ahmad et al., "Understanding the Perception of Islamic Medicine Among the Malaysian Muslim Community", Journal of Religion and Health (JORH), Springer US, (2017), 1-15.

3 Hassan Azaizeh et al., "Traditional Arabic and Islamic Medicine, A ReEmerging Health Aid", eCAM 2010; vol. 7 (4), pp. 419-424. Ibrahim bin Syed, "Spiritual Medicine in the History of Islamic Medicine", JISHIM 2 no. 4 (2003), pp. 45-49.

4 Salim M Adib, "From the Biomedical Model to the Islamic Alternative: A Brief Overview of Medical Practices in the Contemporary Arab World", Social Science and Medicine 58, issue 4 (2004), pp. 697-702. 
tempoh tersebut. Perlu ditegaskan di sini bahawa sumber data senarai pusat-pusat rawatan Islam adalah dikumpulkan hasil daripada sorotan literatur dan carian atas talian terhadap subjek berkaitan. Setelah daripada itu, dilakukan kajian lapangan terhadap pusat-pusat rawatan Islam mencakupi negeri-negeri di Malaysia kecuali Pulau Pinang, Sabah dan Sarawak.

Senarai Pusat Rawatan Alternatif Islam di Malaysia

A. Perlis Indera Kayangan

1. Pusat Perubatan Islam Al-Islah

B. Kedah Darul Aman

1. Pusat Rawatan Islam AlMustaqim

2. Pusat Rawatan Alam Ghaib

3. Azlina Terapi Tradisional (138 Beauty Centre)

4. Pusat Rawatan Aura Zikir

5. Pusat Rawatan Qalbun Sakinah

6. Pusat Rawatan Alternatif Aura Nur Hikmah

7. Pusat Rawatan Tradisional Jabal Nur

8. Pusat Rawatan Amal

9. Pusat Rawatan Terapi AlQuran Darul Hikmah

10. Pusat Terapi Ruqyah Syar'iyyah

C. Perak Darul Ridzuan

1. Pusat Rawatan Islam \& Tarbiah Ilmu Darun Nuraniyyah

2. Pusat Rawatan Al-Quran, Akupuntur, Bekam, Homeopati Ar-Ridhwan

3. AZBUDI Pusat Perubatan Homeopati \& Naturopati

4. Pusat Rawatan Islam Al-Taqwa

5. Pusat Rawatan Islam Ruqyah Isra'

D. Selangor Darul Ehsan

1. Pusat Rawatan Islam AlManarah

2. Persatuan Kebajikan \& Pengubatan Islam Malaysia (Darussyifa')
3. Persatuan Perubatan Islam Darussalam Malaysia Pusat Rawatan Islam IQ Insan

4. D'Urut Hanafi

5. Pusat Rawatan Islam Sepohon Jadi (PRAWIS)

6. Pusat Rawatan Alternatif Rumah Sihat (Bekam Terapi Moden Malaysia)

7. Pusat Rawatan Islam Nur Muhammad

8. Pusat Perubatan Islam Kasturi

9. El-Fesfanji Islamic Traditional Medicine

10. Pusat Rawatan Islam Sinar Zamdurrani

11. Pusat Rawatan Alternatif Nur Islam (PUSRANI)

12. Thibbun Nabawi Healing Centre

13. Pusat Terapi Hikmah (Kedai Bekam \& Resdung) Pusat Rawatan Islam: Penawar Sihir \& Saka

14. Pusat Bekam Sunnah: Nurul Sunnah Entreprise

15. Pusat Rawatan Traditional Aura Nusantara

16. Pusat Rawatan Islam AlHidayah

17. Pusat Rawatan Komplimentari Islam Yashfien

18. Pusat Rawatan Kasturi Syifa'

19. Ismak (Islamic Medicine of Al-Kausar) Ruqyah 
20. Pusat Rawatan Islam Darul Ruqiyyah

21. Akademi Rawatan Islam Nur Ehsan (AKRINE)

22. Nan S Spa Centre (Pusat Rawatan Bekam Nans)

23. Kumpulan Perawat Bandar tasik Puteri Rawang Selangor (PEBATAP)

24. Mohd Baitussyifa' (Rawatan Traditional Secara Islam

E. Negeri Sembilan Darul Khusus

1. Pusat Perubatan Traditional Delima Nurrun Nubuwwah

2. Pusat Rawatan Ruhaniah

3. Pusat Rawatan Islam At-Tobibi

F. Melaka

1. Pusat Rawatan Aura Syifa'

2. Pusat Perubatan Islam 7 Puteri

3. Pusat Rawatan Islam Al-Fatah (TIAF)

4. Pusat Rawatan Alternatif Rohaimi

G. Johor Darul Takzim

1. Pusat Rawatan Alternatif Tradisional Salleh

2. Pusat Rawatan Islam Shah Misteri

3. Baitul Syifa' Kersani (Kersani Training \& Consultancy)

4. Pusat Terapi Islam Al-Barokah

5. Pusat Rawatan Islam

TAPEDIRI 65 (Taqwa,

Pertahanan Diri \& Rawatan Islam)
6. Pusat Rawatan Darul 'Illaj (Pusat Rawatan Islam \& Homeopati)

7. Pusat Perubatan Ahmadiah Sufi

8. Pusat Rawatan Islam Permata Syifa' (Rawatan Bekam Moden \& Terapi Herba)

H.Pahang Darul Makmur

1. Pusat Rawatan Islam Kiswah: Terapi Ruqyah Syar'iyyah

2. Pusat Rawatan As-Syifa'

I. Terengganu Darul Iman

1. Pusat Rawatan Islam AlMadani (PRIA)

2. Pusat Rawatan Ikhtiar Darul Syifa' (PURIDAS)

3. Pusat Perubatan Holistik \& Alternatif

4. Pusat Rawatan Komplimentari Al-Syufia: Bekam \& Refleksologi

5. Pusat Rawatan Islam Darul Manzil (RIDAM)

6. Pusat Rawatan Islam Badan Ukhwah Darul Iman - (BUDI Losong)

J. Kelantan Darul Naim

1. Pusat Rawatan Tradisional AlTunjuniah Al-Fununiah

2. Pusat Rawatan Tradisional Khairey

3. Pusat Rawatan Tradisional \& Bekam

4. Pusat Rawatan Walinur Syifa'

5. Pusat Rawatan Qalbun Asrar

\section{Skop dan Metodologi Kajian}

Kajian ini menilai tahap persepsi masyarakat Muslim terhadap pengubatan Islam di Malaysia. Menggunakan kaedah persampelan secara rawak, responden terdiri daripada 379 orang pesakit yang mengunjungi subjek kajian merangkumi 70 pusat-pusat rawatan Islam. Pesakit-pesakit yang datang ke pusat-pusat rawatan Islam 
akan dinilai persepsi mereka berhubung isu-isu berbangkit, terutama berkaitan prospek masa depan pengubatan Islam di Malaysia. Perlu ditegaskan bahawa ahli keluarga yang menemani pesakit tidak digolongkan sebagai responden kajian.

Pada awal tahun 2013, pilot test telah dijalankan terhadap 100 orang pesakit yang mendapatkan rawatan di Darussyifa' (Persatuan Perubatan Pengubatan dan Kebajikan Malaysia) yang berpangkalan di Bangi, Selangor untuk mengukur tahap validity set borang soal selidik. Subjek dipilih disebabkan beberapa faktor, iaitu antara pusat rawatan yang terawal di Malaysia, mempunyai kalangan ahli dan pengamal yang signifikan, struktur rawatan yang sistematik dan sentiasa dikunjungi oleh pelbagai lapisan masyarakat dari seluruh Malaysia. Semua 100 orang pesakit tersebut telah dipilih secara rawak.

Hasilnya, cronbach's Alpha yang diperoleh adalah .720. Justifikasinya, jumlah tersebut lebih besar daripada julat ditetapkan (0.6). Demikian disimpulkan bahawa keabsahan borang kaji selidik adalah diiktiraf. ${ }^{5}$

\begin{tabular}{|c|c|}
\hline \multicolumn{2}{c|}{ Jadual 1: Reliability Statistics } \\
\hline Cronbach's Alpha & N of Items \\
\hline .720 & 31 \\
\hline
\end{tabular}

Sumber: Soal Selidik (Pertengahan 2013)

Data-data kuantitatif berikut kemudian dianalisis bentuk kekerapan dan rujuk silang mengguna pakai perisian Statistical Package for the Social Science versi 16.0. Ini bertujuan memastikan analisis dan pemprosesan data dilakukan secara tepat serta memperoleh pemahaman yang signifikan daripada respon.

Soal selidik terdiri daripada tiga bahagian, iaitu bahagian A, B dan C. Bagi soalan skala bahagian C, pengkaji menggunakan 5 poin skala mata yang telah dibahagikan kepada pengkelasan sangat tidak setuju, tidak setuju, setuju, sederhana setuju dan sangat setuju.

Daripada itu, ditetapkan tiga kategori tahap penilaian persepsi sebagaimana di atas. Ini membenarkan untuk membuat kesimpulan dan menginterpretasikan data yang relevan daripada skala jawapan yang selari dengan tahap persepsi responden.

5 Yusmini Md. Yusoff, "Malaysian Muslim Counsellors' Perceptions on ValueNeutral Stance and Religious Values in Counseling Practice A Preliminary Study," Jurnal Usuluddin, 40 (2014), 173-198. 
Jadual 2: Tahap Persepsi Responden Berdasarkan Skala Jawapan

\begin{tabular}{|l|c|c|}
\hline \multicolumn{1}{|c|}{ Skala Jawapan } & Tahap Persepsi & Julat Skor \\
\hline $\begin{array}{l}\circ \text { Sangat Tidak Setuju } \\
\circ \text { Tidak Setuju }\end{array}$ & Rendah & $1.00-2.33$ \\
\hline$\circ$ Setuju & Sederhana & $2.331-3.66$ \\
\hline $\begin{array}{l}\text { O Sederhana Setuju } \\
\text { S Sangat Setuju }\end{array}$ & Tinggi & $3.661-5.00$ \\
\hline
\end{tabular}

\section{Dapatan Kajian}

\section{Bahagian A: Latar Belakang Responden}

Soalan 1-5 bahagian A soal selidik dirangka bagi memperoleh butir-butir peribadi responden.

Jadual 3: Demografi Responden

\begin{tabular}{|c|c|c|c|}
\hline \multicolumn{2}{|c|}{ Latar Belakang Responden } & Kekerapan & Peratusan \\
\hline \multirow{3}{*}{ Jantina } & Lelaki & 199 & 52.5 \\
\hline & Perempuan & 180 & 47.5 \\
\hline & Jumlah & 379 & 100.0 \\
\hline \multirow{6}{*}{ Umur } & 17 tahun ke bawah & 9 & 2.4 \\
\hline & 18 tahun - 29 tahun & 127 & 33.5 \\
\hline & 30 tahun - 40 tahun & 92 & 24.3 \\
\hline & 41 tahun - 50 tahun & 71 & 18.7 \\
\hline & 51 tahun ke atas & 80 & 21.1 \\
\hline & Jumlah & 379 & 100.0 \\
\hline \multirow{4}{*}{ Status } & Belum berkahwin & 136 & 35.9 \\
\hline & Berkahwin & 215 & 56.7 \\
\hline & Duda/Janda & 28 & 7.4 \\
\hline & Jumlah & 379 & 100.0 \\
\hline \multirow{7}{*}{$\begin{array}{l}\text { Taraf } \\
\text { Pendidikan } \\
\text { Tertinggi }\end{array}$} & Sekolah Rendah & 27 & 7.1 \\
\hline & Pondok/Pesantren & 14 & 3.7 \\
\hline & Sekolah Menengah & 129 & 34.0 \\
\hline & IPT Dalam Negara & 175 & 46.2 \\
\hline & IPT Luar Negara & 33 & 8.7 \\
\hline & Lain-lain & 1 & 0.3 \\
\hline & Jumlah & 379 & 100.0 \\
\hline \multirow{7}{*}{ Pekerjaan } & Kerajaan & 105 & 27.7 \\
\hline & Badan Berkanun & 31 & 8.2 \\
\hline & Swasta & 100 & 26.4 \\
\hline & Bekerja Sendiri & 61 & 16.1 \\
\hline & Tidak Bekerja & 55 & 14.5 \\
\hline & Pelajar & 27 & 7.1 \\
\hline & Jumlah & 379 & 100.0 \\
\hline
\end{tabular}

Sumber: Soal Selidik (Pertengahan 2013) 


\section{Bahagian B: Interaksi Terhadap Pengubatan Islam di Malaysia}

Dalam bahagian ini, analisis dilakukan terhadap pengetahuan dan interaksi responden terhadap pengubatan Islam di Malaysia. Interaksi di sini memberi maksud mengkaji hubungan aktif responden terhadap pusat rawatan yang terdapat di Malaysia. Berikut merupakan dapatan kajian merujuk kepada jawapan untuk soalan B1-B6.

Jadual 4: Pengetahuan dan Interaksi Responden Terhadap Rawatan Alternatif Berteraskan Islam di Malaysia

\begin{tabular}{|c|c|c|c|c|}
\hline Bil. & Soalan & Jawapan & Kekerapan & Peratusan \\
\hline \multirow{3}{*}{ B1 } & Pengetahuan & Ya & 368 & 97.1 \\
\hline & mengenai & Tidak & 11 & 2.9 \\
\hline & kewujudan & Jumlah & 379 & 100.0 \\
\hline \multirow{3}{*}{ B2 } & \multirow{3}{*}{$\begin{array}{l}\text { Pernah dapat } \\
\text { rawatan }\end{array}$} & Ya & 346 & 91.3 \\
\hline & & Tidak & 33 & 8.7 \\
\hline & & Jumlah & 379 & 100.0 \\
\hline \multirow{7}{*}{ B3 } & \multirow{7}{*}{$\begin{array}{l}\text { Bentuk pusat } \\
\text { rawatan } \\
\text { yang dirujuk }\end{array}$} & Rawatan Berteraskan Islam & 318 & 83.9 \\
\hline & & Pusat Rawatan Bekam & 26 & 6.9 \\
\hline & & Rawatan Tradisional (Bomoh, & & \\
\hline & & dukun) & 32 & 8.4 \\
\hline & & Pusat Rawatan Allopati & 1 & 0.3 \\
\hline & & Lain-lain & 2 & 0.5 \\
\hline & & Jumlah & 379 & 100.0 \\
\hline \multirow{6}{*}{ B4 } & \multirow{6}{*}{$\begin{array}{l}\text { Bentuk } \\
\text { rawatan } \\
\text { yang dirujuk }\end{array}$} & Penyakit yang disebabkan oleh & & \\
\hline & & gangguan makhluk halus & 312 & 82.3 \\
\hline & & Penyakit fizikal & 34 & 9.0 \\
\hline & & $\begin{array}{l}\text { Penyakit yang berkaitan j1wa } \\
\text { atau mental }\end{array}$ & 28 & 7.4 \\
\hline & & Lain-lain & 5 & 1.3 \\
\hline & & Jumlah & 379 & 100.0 \\
\hline \multirow{8}{*}{ B5 } & \multirow{8}{*}{$\begin{array}{l}\text { Dorongan } \\
\text { merujuk }\end{array}$} & $\begin{array}{l}\text { Kesukaran hospital atau klinik } \\
\text { untuk mengubati pesakit } \\
\text { Lebih yakin dengan pendekatan }\end{array}$ & 133 & 35.1 \\
\hline & & dalam rawatan Islam & 96 & 25.3 \\
\hline & & Mencuba sesuatu yang baru & 40 & 10.6 \\
\hline & & $\begin{array}{l}\text { Desakan daripada ahlı keluarga } \\
\text { atau rakan-rakan }\end{array}$ & 24 & 6.3 \\
\hline & & Kemahuan sendiri mendapatkan & & \\
\hline & & rawatan berteraskan Islam & 84 & 22.2 \\
\hline & & Lain-lain & 2 & 0.5 \\
\hline & & Jumlah & 379 & 100.0 \\
\hline
\end{tabular}




\begin{tabular}{|c|c|c|c|c|}
\hline Bil. & Soalan & Jawapan & Kekerapan & Peratusan \\
\hline \multirow{7}{*}{ B6 } & \multirow{7}{*}{$\begin{array}{l}\text { Sumber } \\
\text { pengetahuan }\end{array}$} & Media Massa & 100 & 26.4 \\
\hline & & Media Elektronik & 55 & 14.5 \\
\hline & & Iklan papar tanda & 25 & 6.6 \\
\hline & & Makluman daripada rakan-rakan & & \\
\hline & & / ahli keluarga & 174 & 45.9 \\
\hline & & Usaha sendiri mencari & 25 & 6.6 \\
\hline & & Jumlah & 379 & 100.0 \\
\hline
\end{tabular}

Sumber: Soal Selidik (Pertengahan 2013)

\section{Bahagian C: Potensi Masa Hadapan Pengubatan Islam di Malaysia}

Dalam bahagian ini, analisis dijalankan berhubung prospek masa hadapan pengubatan Islam di Malaysia. Berikut merupakan dapatan kajian merujuk kepada jawapan untuk soalan skala C1C3.

Jadual 5: Persepsi Responden Terhadap Masa Hadapan Rawatan Alternatif Berteraskan Islam di Malaysia

\begin{tabular}{|l|l|l|c|c|}
\hline Bil. & \multicolumn{1}{|c|}{ Soalan } & \multicolumn{1}{|c|}{ Skala Jawapan } & Kekerapan & Peratusan \\
\hline \multirow{5}{*}{ C1 } & Pusat rawatan alternatif & Sangat Tidak Setuju & 3 & 8 \\
& Islam akan berkembang & Tidak Setuju & 9 & 2.4 \\
& dengan pesat dan & Setuju & 98 & 25.9 \\
& mempunyai masa depan & Sederhana Setuju & 114 & 30.1 \\
& yang cerah & Sangat Setuju & 155 & 40.9 \\
& Jumlah & 379 & 100.0 \\
\hline \multirow{5}{*}{ C2 } & \multirow{3}{*}{ Pusat rawatan alternatif } & Sangat Tidak Setuju & 17 & 4.5 \\
& Tslam boleh mengambil & Tidak Setuju & 90 & 23.7 \\
& alih tempat/peranan & Setuju & 123 & 32.5 \\
& hospital dan klinik & Sederhana Setuju & 85 & 22.4 \\
& & Sangat Setuju & 64 & 16.9 \\
& & Jumlah & 379 & 100.0 \\
\hline \multirow{5}{*}{ C3 } & Sangat Tidak Setuju & 6 & 1.6 \\
& Pusat rawatan alternatif & Tidak Setuju & 18 & 4.7 \\
& Islam boleh bergabung & Setuju & 107 & 28.2 \\
& dengan hospital/klinik & Sederhana Setuju & 107 & 28.2 \\
& & Sangat Setuju & 141 & 37.2 \\
& & Jumlah & 379 & 100.0 \\
\hline
\end{tabular}

Sumber: Soal Selidik (Pertengahan 2013)

Dalam pada itu, dilaksanakan analisis rujuk silang bagi mengkaji signifikan antara demografi responden terhadap soalan C1. Ini penting bagi memahami elemen yang mempengaruhi 
pemilihan jawapan responden. Hasilnya boleh dilihat pada dua jadual berikut:

Jadual 6: Analisis Rujuk Silang (Cross-Tabulation)

Antara Umur Terhadap Soalan C1

\begin{tabular}{|c|c|c|c|c|c|c|c|}
\hline \multicolumn{7}{|c|}{$\begin{array}{c}\text { SC1: Pusat rawatan alternatif Islam bakal berkembang } \\
\text { dengan lebih pesat dan maju pada masa akan datang }\end{array}$} \\
\hline & $\begin{array}{c}\text { Sangat } \\
\text { Tidak } \\
\text { Setuju }\end{array}$ & $\begin{array}{c}\text { Tidak } \\
\text { Setuju }\end{array}$ & Setuju & $\begin{array}{c}\text { Sederhana } \\
\text { Setuju }\end{array}$ & $\begin{array}{c}\text { Sangat } \\
\text { Setuju }\end{array}$ & Jumlah \\
\hline \multicolumn{2}{|c|}{} & 0 & 1 & 2 & 3 & 3 & 9 \\
\hline & 3 & 1 & 30 & 40 & 53 & 127 \\
\hline $18-29$ & 37 & 0 & 0 & 29 & 26 & 37 & 92 \\
\hline $30-40$ & 0 & 6 & 14 & 19 & 32 & 71 \\
\hline $41-50$ & 0 & 1 & 23 & 26 & 30 & 80 \\
\hline $51>$ & 3 & 9 & 98 & 114 & 155 & 379 \\
\hline
\end{tabular}

Jadual 7: Chi-Square Tests

\begin{tabular}{|l|c|c|c|}
\hline & Value & $d f$ & $\begin{array}{c}\text { Asymp. Sig. } \\
(2 \text {-sided })\end{array}$ \\
\hline Pearson Chi-Square & $27.888^{\mathrm{a}}$ & 16 & .033 \\
\hline Likelihood Ratio & 25.464 & 16 & .062 \\
\hline Linear-by-Linear Association & .001 & 1 & .969 \\
\hline Nof Valid Cases & 379 & & \\
\hline $\begin{array}{l}\text { a. 13 sel (52.0\%) telah memenuhi jangkaan dengan hasil kurang } \\
\text { daripada 5. Jumlah minimum yang dijangkakan adalah .07. }\end{array}$ \\
\hline
\end{tabular}

Dalam jadual berikut, taburan tertinggi responden terdiri daripada golongan berumur daripada 18 hingga 29 tahun dengan majoriti "sangat setuju" bahawa dengan kenyataan "pusat rawatan Islam bakal berkembang dengan lebih pesat dan maju pada masa akan datang" dengan jumlah 53 orang, diikuti 40 "sederhana setuju" dan 30 "setuju." Seterusnya, bagi golongan berumur daripada 30 hingga 40 tahun, seramai 37 orang mengatakan "sangat setuju", 26 orang "sederhana setuju" dan 29 orang "setuju". Taburan terendah responden pula yang berumur 17 tahun ke bawah.

Dalam pada itu, chi-square test menunjukkan keputusan $\chi^{2}=27.888, \mathrm{df}=16, \mathrm{p}<0.05$ yang mana keputusan tersebut mempunyai signifikan antara umur dengan soalan C1. Angka standard residual adalah kecil (0.1-1.0). Kesimpulannya, umur responden mempengaruhi pemilihan jawapan dalam soalan $\mathrm{C} 1$. 
Demikian dapat dirumuskan semua peringkat umur mempunyai keyakinan dan persepsi yang tinggi terhadap prospek masa hadapan pengubatan Islam di Malaysia.

Selain daripada itu, pengkaji turut mengkaji signifikan demografi responden terhadap soalan C3. Hal ini sebagaimana dua jadual berikut:

Jadual 8: Analisis Rujuk Silang (Cross-Tabulation) Antara Taraf Pendidikan Tertinggi Terhadap Soalan C3

SC3: Pusat rawatan alternatif Islam boleh berkembang apabila bergabung dengan hospital dan klinik

\begin{tabular}{|c|c|c|c|c|c|c|c|}
\hline & $\begin{array}{l}\text { Sangat } \\
\text { Tidak } \\
\text { Setuju }\end{array}$ & $\begin{array}{l}\text { Tidak } \\
\text { Setuju }\end{array}$ & Setuju & $\begin{array}{c}\text { Sederhana } \\
\text { Setuju }\end{array}$ & $\begin{array}{l}\text { Sangat } \\
\text { Setuju }\end{array}$ & Jumlah \\
\hline \multirow{6}{*}{ 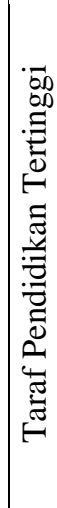 } & $\begin{array}{l}\text { Sekolah } \\
\text { Rendah }\end{array}$ & 0 & 1 & 4 & 14 & 8 & 27 \\
\hline & $\begin{array}{l}\text { Pondok/ } \\
\text { Pesantren }\end{array}$ & 1 & 0 & 4 & 3 & 6 & 14 \\
\hline & $\begin{array}{c}\text { Sekolah } \\
\text { Menengah }\end{array}$ & 4 & 10 & 41 & 22 & 52 & 129 \\
\hline & $\begin{array}{l}\text { IPT Dalam } \\
\text { Negara }\end{array}$ & 1 & 6 & 47 & 55 & 66 & 175 \\
\hline & $\begin{array}{l}\text { IPT Luar } \\
\text { Negara }\end{array}$ & 0 & 1 & 11 & 13 & 8 & 33 \\
\hline & Lain-lain & 0 & 0 & 0 & 0 & 1 & 1 \\
\hline & Jumlah & 6 & 18 & 107 & 107 & 141 & 379 \\
\hline
\end{tabular}

Jadual 9: Chi-Square Tests

\begin{tabular}{|l|c|c|c|}
\hline & Value & $d f$ & $\begin{array}{c}\text { Asymp. Sig. } \\
(2 \text {-sided })\end{array}$ \\
\hline Pearson Chi-Square & $30.860^{\mathrm{a}}$ & 20 & .057 \\
\hline Likelihood Ratio & 31.430 & 20 & .050 \\
\hline Linear-by-Linear Association & .031 & 1 & .861 \\
\hline N of Valid Cases & 379 & & \\
\hline
\end{tabular}

a. 15 sel (50.0\%) telah memenuhi jangkaan dengan hasil kurang daripada 5. Jumlah minimum yang dijangkakan adalah .02 .

Dalam jadual 9 dan 10, taburan tertinggi responden yang berlatarbelakangkan pendidikan IPT dalam negara secara majoriti "sangat setuju" dengan pernyataan bahawa "pusat rawatan Islam boleh berkembang apabila bergabung dengan hospital dan klinik" seramai 66 orang, 55 orang "sederhana setuju" dan 47 orang "setuju". Ini diikuti responden berlatarbelakangkan pendidikan 
sekolah menengah seramai 52 orang "sangat setuju", 41 "setuju" dan 22 "sederhana setuju. Taburan responden terendah adalah berlatarbelakangkan pendidikan pondok/pesantren.

Di samping itu, chi-square test menunjukkan keputusan $\chi^{2}=30.860, \quad \mathrm{df}=20, \mathrm{p}<0.05$ yang mana keputusan tersebut mempunyai signifikan antara taraf pendidikan tertinggi dengan soalan C3 Angka standard residual adalah kecil (0.1-1.0). Kesimpulannya, taraf pendidikan tertinggi adalah mempengaruhi pemilihan jawapan responden terhadap soalan C3. Walaupun begitu, jawapan setuju dan sederhana setuju berada pada taburan sekata iaitu dengan 107 mata. Hal ini membuktikan persepsi responden terhadap penyatuan pusat rawatan alternatif Islam dengan institusi kesihatan kontemporari adalah berada pada tahap yang sederhana.

\section{Perbincangan dan Rumusan Kajian}

Berdasarkan dapatan yang dinyatakan dalam perbahasan terdahulu, majoriti responden sebanyak $91.3 \%$ pernah merujuk kepada khidmat rawatan alternatif. Subjek turut mengetahui kewujudan pusat rawatan Islam di Malaysia dengan peratusan sebanyak $97.1 \%$. Secara lebih terperinci, pengetahuan responden dalam hal ini adalah bertitik tolak daripada maklumat yang disalurkan rakan-rakan atau ahli keluarga (45.9\%) dan media massa $(26.4 \%)$.

Dalam pada itu, pengubatan Islam menunjukkan jumlah rujukan tertinggi oleh masyarakat sebanyak 83.9\%. Ini membuktikan peranan penting pengubatan alternatif berteraskan Islam kepada masyarakat Muslim di Malaysia berbanding pengubatan alternatif yang lain. Apabila dikaji dengan lebih mendalam, hal ini didorong oleh beberapa faktor, iaitu: (1) kesukaran pihak institusi kesihatan moden untuk merawat pesakit tertentu dengan peratusan sebanyak $35.1 \%$. (2) lebih berkeyakinan dan percaya kepada pendekatan dalam pengubatan Islam dengan peratusan $25.3 \%$, dan (3) kesedaran atau kemahuan kendiri merujuk kepada khidmat pengubatan Islam (22.2\%). Mengambil contoh daripada dapatan soal selidik, penyakit yang mencatat taburan tertinggi rujukan oleh masyarakat adalah gangguan makhluk halus dengan jumlah sebanyak $82.3 \%$, diikuti penyakit fizikal 9.0\%, dan penyakit berkaitan emosi/rohani (7.4\%). 
Hasil sorotan literatur turut mendapati bahawa masyarakat Muslim cenderung kepada pemilihan pengubatan alternatif disebabkan tidak berpuas hati dengan kaedah rawatan moden. Kedua, rawatan mampu memberikan sepenuh kuasa kepada pesakit untuk membuat keputusan. Ketiga, kaedah rawatan yang lebih sesuai dengan worldview dan self beliefs pesakit. ${ }^{6}$ Dalam erti kata yang lain, faktor pemilihan oleh pesakit adalah mendorong kepada peningkatan tahap keyakinan terhadap kaedah pengubatan Islam sebagai sokongan kepada rawatan moden.

Seterusnya merujuk kepada prospek masa hadapan pusat rawatan Islam, hasil analisis telah diringkaskan dalam rajah berikut:

Rajah 1: Rumusan Keseluruhan Hasil Dapatan

Rumusan Analisis Prospek Masa Hadapan

Rawatan Alternatif Berteraskan Islam

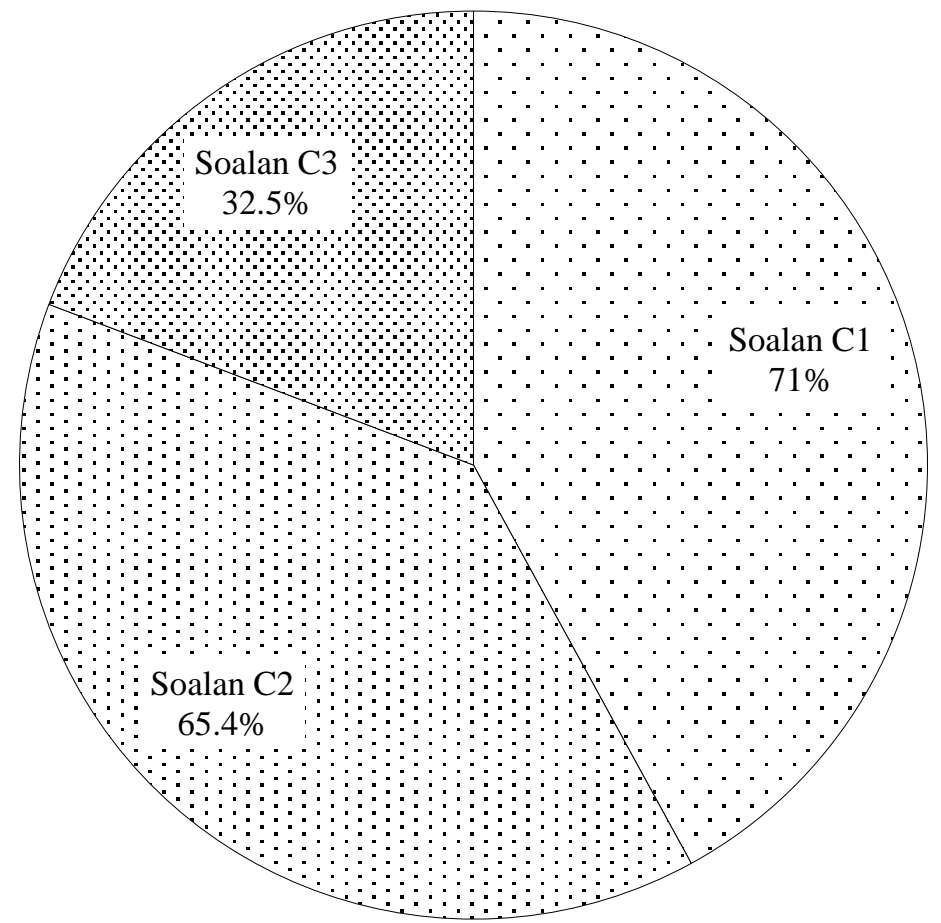

Sumber: Soal Selidik (Pertengahan 2013)

6 John A. Astin, "Why Patients Use Alternative Medicine: Results of a National Study", JAMA 1998; 279 (19), pp. 1548- 1553. 
Daripada gabungan keseluruhan data jawapan tertinggi responden berkaitan jangkaan potensi masa hadapan pengubatan Islam di Malaysia, dapat disimpulkan secara deskriptif bahawa sokongan terhadap pusat rawatan Islam dalam kalangan responden adalah amat memberangsangkan. Ini ditunjukkan dalam soalan C1 "Pengubatan Islam bakal berkembang dengan pesat dan mempunyai masa depan yang cerah" dan C3 "Pusat rawatan Islam boleh bergabung dengan hospital dan klinik". Majoriti responden secara purata dengan masing-masing sebanyak $71 \%$ dan $65.4 \%$ memaparkan persepsi tahap tinggi berhubung paradigma subjek untuk berkembang dan peluang integrasi dengan institusi moden.

Manakala dalam soalan $\mathrm{C} 2$, respons tertinggi responden menyatakan pandangan pertengahan (setuju) bagi analisis jawapan subjek tersebut "Pusat rawatan Islam boleh mengambil alih peranan hospital dan klinik dalam rawatan penyakit" sebanyak $32.5 \%$. Oleh hal yang demikian, tahap persepsi masyarakat dalam isu "pengambilalihan peranan" adalah berada pada tahap sederhana.

Berdasarkan analisis rujuk silang yang telah dilakukan, naratif keyakinan yang ditunjukkan dalam kalangan masyarakat Muslim terhadap potensi masa hadapan pusat rawatan Islam untuk berkembang maju adalah berada pada tahap tinggi. Hal ini disokong oleh semua lapisan masyarakat daripada usia 18 sehingga kepada 51 tahun ke atas yang mengunjungi pusat-pusat rawatan Islam seluruh Malaysia.

Sementara itu, persepsi tahap tinggi turut ditonjolkan masyarakat agar diwujudkan jalinan integrasi antara pusat rawatan Islam dengan institusi kesihatan kontemporari terutamanya daripada golongan berpendidikan tinggi. Hal ini turut disokong golongan berpendidikan sekolah rendah, sekolah menengah dan pondok/pesantren. Dalam erti kata yang lain, hal ini mendapat dukungan semua lapisan masyarakat daripada pelbagai latar belakang.

Sehubungan dengan itu, rumusan kajian yang dapat dinyatakan adalah: Pertama; respons dan permintaan masyarakat Muslim terhadap kaedah pengubatan Islam adalah tinggi. Para responden cukup yakin dengan prospek perkembangan bidang pengubatan Islam di Malaysia yang lebih pesat. Kedua; kerangka 
cadangan untuk diwujudkan gabungan antara pengubatan Islam dengan institusi kesihatan kontemporari adalah amat memberangsangkan. Hal demikian walaupun memerlukan sedikit masa untuk dilaksanakan proses adaptasi secara menyeluruh, penting bagi memenuhi kehendak masyarakat semasa. Ketiga; pengubatan tradisional perlu terus dibangunkan walaupun persepsi responden membuktikan kecenderungan kepada pemilihan pengubatan moden sebagai langkah lebih mujarab. Justifikasinya, $70 \%$ populasi di negara membangun masih bergantung kepada sistem pengubatan komplementari, terutama di kawasan kampung atau desa. ${ }^{7}$

Sebagai kesimpulan, kombinasi antara pengubatan Islam dan kontemporari perlu dilaksanakan. Hal ini kerana pengubatan Islam perlu bergerak seiringan dengan kemajuan teknologi. Walau bagaimanapun, solusi terbaik dalam rawatan penyakit bukan dengan cara pengambil alih peranan institusi kesihatan semasa. Oleh demikian, hal ini perlu diperhalusi bagi memelihara kepentingan bersama.

Dalam hal ini, pengubatan Islam adalah penting dan bermanfaat kepada masyarakat di Malaysia. Walau bagaimanapun, subjek mungkin mencetuskan bahaya vice versa terhadap pesakit jika terus diabaikan rujukan terhadap pusat pengubatan kontemporari dalam usaha ikhtiar kesembuhan penyakit. Akhirnya bagi menangani isu responden yang masih kurang yakin terhadap prospek pusat rawatan Islam, pendedahan secara intelektual perlu diberikan secara tadarruj (perlahan-lahan) agar masyarakat mampu menerima dan memahami peranan pengubatan Islam secara total.

\section{Penghargaan}

Fundamental Research Grant Scheme (FRGS) -FP025-2015A"Indeks Patuh Syariah Pengubatan Alternatif Islam di Malaysia."

Hassan Azaizeh et al., "Traditional Arabic and Islamic Medicine, A ReEmerging Health Aid", $e C A M$, 7, issue.4 (2010), pp. 419-424. 


\section{Rujukan}

Esther Walcott. "Seni Pengobatan Alternatif: Pengetahuan dan Persepsi". Kerja Kursus Program Australian Consortium for in Country Indonesia Studies (ACICIS). Malang, Indonesia: Universitas Muhammadiyah, 2004.

Hassan Azaizeh et.al, "Traditional Arabic and Islamic Medicine, A Re-Emerging Health Aid." eCAM 7, no.4 (2010): 419-424.

Ibrahim bin Syed. "Spiritual Medicine in the History of Islamic Medicine". JISHIM 2, Issue 4 (2003): 45-49.

John A. Astin. "Why Patients Use Alternative Medicine: Results of A National Study". JAMA 279, 19 (1998): 1548- 1553.

Khadher Ahmad et al. "Understanding the Perception of Islamic Medicine Among the Malaysian Muslim Community". Journal of Religion and Health (JORH), Springer US, (2017) (e-ISSN 1573-6571), 1-15.

Khadher Ahmad, Mohd Farhan Md Ariffin \& Ishak Suliaman. "Pusat Rawatan Alternatif Islam di Malaysia: Analisis Terhadap Latar Belakang Pengasas dan Isu Penggunaan Jin dalam Rawatan". Jurnal Usuluddin 20 (2014): 71-98.

M Adib, Salim "From The Biomedical Model to the Islamic Alternative: A Brief Overview of Medical Practices in the Contemporary Arab World". Social Science and Medicine 58, Issue 4 (2004): 697-702.

Norhafizah Musa \& Che Zarrina Sa'ari. "Pendekatan Psikoterapi Islam dalam Menguruskan Tekanan Pesakit Kronik". Jurnal Usuluddin 47, 1 (2019): 1-34.

Timmermans, Karin. ASEAN Workshop: TRIPS, CBD and Traditional Medicines: Concepts and Questions. Jakarta, n.p 2001), 13-15:02.01.

Werner, Roland. Transcultural Healing, the Whole Human. Kuala Lumpur: University Malaya Press, 1983.

$\mathrm{Xu}$ Hao, Chen Ke-Ji. Complementary and Alternative Medicine: Is it Possible to be Mainstream? Chin J Integr Med 18, 6 (2012): 403-404. 